\title{
An efficient gene disruption method for the woody plant pathogen Botryosphaeria dothidea
}

\author{
Bao-Zhu Dong ${ }^{1}$ and Li-Yun Guo ${ }^{1,2^{*}}$
}

\begin{abstract}
Background: Botryosphaeria dothidea causes apple white rot and infects many tree plants. Genome data for B. dothidea are available and many pathogenesis-related genes have been predicted. However, a gene manipulation method is needed to study the pathogenic mechanism of $B$. dothidea.

Results: We established a gene disruption (GD) method based on gene homologous recombination (GHR) for $B$. dothidea using polyethylene glycol-mediated protoplast transformation. The results showed that a GHR cassette gave much higher GD efficiency than a GHR plasmid. A high GD efficiency ( $1.3 \pm 0.14$ per $10^{6}$ protopasts) and low frequency of random insertions were achieved with a DNA cassette quantity of $15 \mu \mathrm{g}$ per $10^{6}$ protoplasts. Moreover, we successfully disrupted genes in two strains. Bdo_05381-disrupted transformants produced less melanin, whereas the Bdo_02540-disrupted transformant showed a slower growth rate and a stronger resistance to Congo red.

Conclusion: The established GD method is efficient and convenient and has potential for studying gene functions and the pathogenic mechanisms of $B$. dothidea and other coenocytic fungi.
\end{abstract}

Keywords: Botryosphaeria dothidea, Tree pathogen, Gene disruption, Homologous recombination

\section{Background}

Botryosphaeria dothidea is a pathogen found worldwide that can infect hundreds of woody plant species [1], including apple, peach [2], eucalyptus [3], grape [4], pecan [5], and blueberry [6], and cause fruit rot, leaf spot, twig dieback, stem and branch canker, and tree death [7]. Apple white rot caused by $B$. dothidea is one of the most destructive diseases in China [8]. B. dothidea is a coencytic fungus. Colony in culture is whitish at beginning, and changes to olivaceous, dark grey, and black in reverse as it ages. In nature, it reproduces commonly through producing conidia contained in pycnidia, and

\footnotetext{
* Correspondence: ppguo@cau.edu.cn

'Laboratory of Mycology, College of Plant Protection, China Agricultural University, Beijing 100193, China

${ }^{2}$ Key Laboratory of Pest Monitoring and Green Management, College of Plant Protection, China Agricultural University, Beijing 100193, China
}

occasionally through producing ascospores [1]. Pycnidia produced on culture are also dark colored due to the melanin accumulation. Melanin can protect organisms from environmental stress [9].

B. dothidea has a genome size of $43-45 \mathrm{Mb}[1,10-$ 12]. Although the genomic sequence of $B$. dothidea is available and many pathogenesis-related genes have been predicted, its pathogenic mechanism is still unclear. This is mainly due to the lack of an efficient genetic manipulation method for this pathogen.

Commonly used methods for investigating gene functions include gene disruption (GD) through homologous recombination (gene targeting) [13], gene mutagenesis through T-DNA insertion [14-16], gene editing through CRISPR/Cas9 [17] and gene silencing through RNAi [18]. Among these methods, GD through homologous recombination is the most commonly used for studying 
gene functions in filamentous phytopathogenic fungi, including Fusarium graminearum [19], Verticillium dahliae [20], and Magnaporthe oryzae [21]. The power of GD by homologous recombination is that researchers can choose precisely both the gene to disrupt and the specific change to introduce [22]. Recently, polyethylene glycol (PEG)-mediated protoplast transformation and Agrobacterium tumefaciens-mediated transformation methods have been established for B. dothidea [23, 24], but an efficient GD method remains to be developed.

In this study, we selected two genes, Bdo_05381 (a predicted pheromone precursor protein) and Bdo_02540 (a hypothetical protein), which were up-regulated during the process of infection and the melanin accumulation [25], as targets to develop the disruption method. We successfully established a convenient and efficient protocol for GD based on gene homologous recombination (GHR) for B. dothidea through PEG-mediated protoplast transformation.

\section{Results}

Using a GHR cassette for transformation gives higher GD efficiency

The hygromycin-resistance gene $(h p h)$ activated by $\operatorname{tr} p \mathrm{C}$ promoter was used for resistance selection. For homologous replacement, a $1000 \mathrm{bp}$ fragment of $5^{\prime}$ flanking sequences of the target gene was fused to the $5^{\prime}$ terminus of $h p h$, and a same size of $3^{\prime}$ flanking sequences of the target gene was fused to the 3' teminus. When the homologous recombination happens on both upstream and downstream, the target gene is replaced by $h p h$ (Fig. 1). The correct GD transformant will have only one $h p h$ gene locus. When PCR verification is used to examine the GD transformants, about 1-kbp PCR products of upstream (with P1 and P2) and downstream (with P3 and
P4) will be amplified. The open reading frame fragment (ORF) will be absent in the PCR product with P5 and P6. The PCR product of GD transformants will be 400bp longer than wild type with P1 and P4 (Fig. 1).

When $10 \mu \mathrm{g}$ of GHR cassette was used for transformation, 39 transformants were obtained for Bdo_05381 (Table 1). The transformation efficiency was $3.9 \pm 0.71$ per $10^{6}$ protoplasts. B. dothidea is a coenocytic fungus. When PCR verification was applied, various patterns of PCR results were observed in PCR verification of GD. If there are two or multiple haploid nuclei in one cell, and only random insertion happened, the results of PCR verification will be same as the wild type, like No. 2 in Fig. 2. If homologous recombination happens in all nucleus, and the target gene is fully disrupted, result of PCR will be same as the No. 1, 7, 10, 12, 13, 16 and 17 in Fig. 2. If homologous recombination happens in partial nucleus, result of PCR will be the superposition by wild type and successfully disrupted nucleus, result of PCR will be same as the No. 14 and 15 in Fig. 2. If recombination happens only on upstream or downstream fragment in partial nuclei (Additional file 1: Figure S1), the pattern of PCR products will be superposition by wild type and incomplete disrupted nuclei, like No. 3-6, 8 and 11 in Fig. 2. If homologous recombination happens only on downstream fragment in all nuclei, result of PCR will be the same as No. 9 in Fig. 2.

Among the 39 transformants, nine showed upstream (amplified with P1 and P2) and downstream fragments (amplified with P3 and P4) of Bdo_05381 of the correct size, 400-bp longer amplicons than Bdo_05381 (amplified by P1 and P4), and the absence of the ORF fragment (amplified with P5 and P6) (Figs. 1, 2), like No. 1, 7, 10, 12, 13, 16 and 17 in Fig. 2, indicating that Bdo_05381 was successfully disrupted. Thus, the GD efficiency was

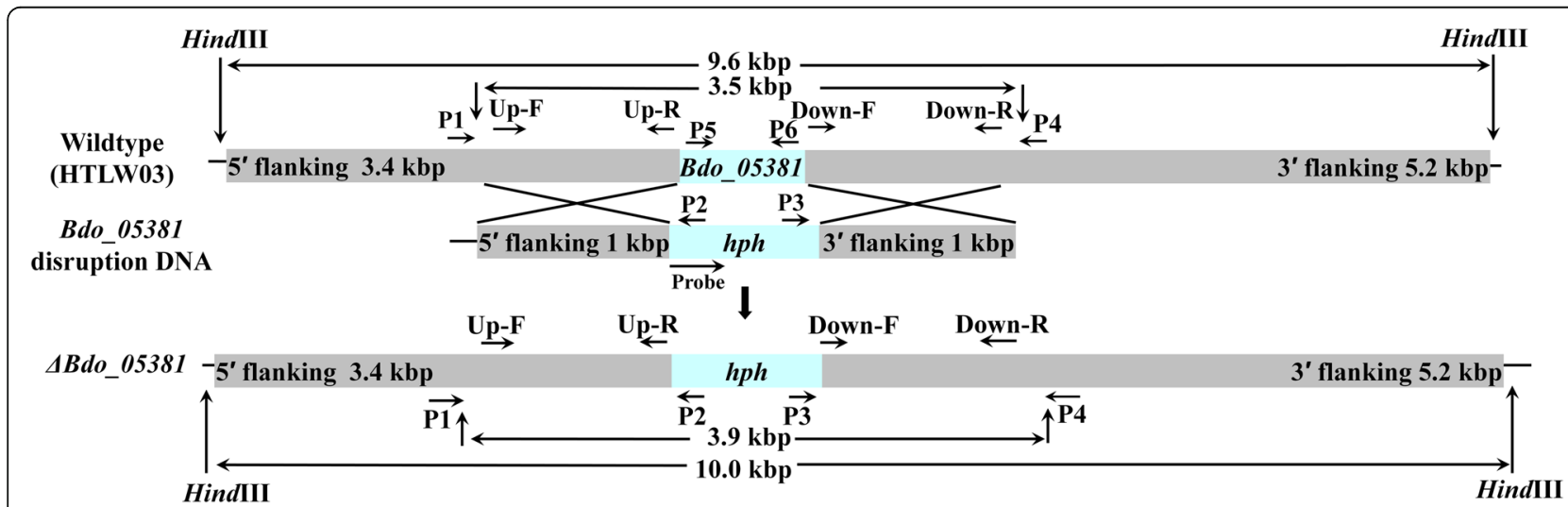

Fig. 1 Homologous recombination strategy and primers used for verifying the Bdo_05381-disrupted transformants. Arrows indicate the positions of the primers used for constructing the plasmid and for verifying the transformants by PCR. The restriction enzyme digestion sites are marked. The hph gene controlled by the trpC promoter was used as the resistance marker. The $5^{\prime}$ and $3^{\prime}$ fragments flanking the target gene were linked to the sequences upstream and downstream of hph, respectively, to disrupt the target gene. A 500-bp hph gene probe was used for a Southern blot analysis 
Table 1 Disruption efficiency of transforming B. dothidea HTLW03 with plasmid or cassette

\begin{tabular}{llllll}
\hline Gene ID & DNA & No. of transformants & $\begin{array}{l}\text { No. of correct } \\
\text { transformants }\end{array}$ & $\begin{array}{l}\text { Transformation efficiency } \\
\text { (No. of transformants/10 } \text { protoplasts) }\end{array}$ & $\begin{array}{l}\text { GD efficiency } \\
\text { (No. of transformants/10 }{ }^{7} \text { protoplasts) }\end{array}$ \\
\hline Bdo_05381 & Cassette & 39 & 9 & $3.9 \pm 0.71$ & $9.0 \pm 2.1 \mathrm{a}$ \\
& Plasmid & 22 & 1 & $2.2 \pm 0.28$ & $1.0 \pm 1.4 \mathrm{~b}$ \\
\hline
\end{tabular}

Molar mass of 4.34 pmol transforming plasmid or disruption cassette were used. Values are means \pm SD from two independent experiments. Values followed with different letters are significantly different according to ANOVA and Duncan's method $(P<0.05)$

$9.0 \pm 2.1$ transformants per $10^{7}$ protoplasts. When the same molar-mass of GHR plasmid was used, which contained the same $5^{\prime}$ and $3^{\prime}$ flanking sequences and $h p h$, the GD efficiency was decreased to $1.0 \pm 1.4$ transformants per $10^{7}$ protoplasts (Table 1 ). This result showed that using a GHR cassette gave higher GD efficiency than using a GHR plasmid.

\section{Optimization of GHR cassette quantity for higher GD efficiency}

We next tested the effect of GHR cassette quantity on GD efficiency targeting Bdo_05381. When various amounts of GHR cassette DNA were used for transformation, 5-17 GD transformants were obtained (Table 2). The transformation efficiency ranged from $2.7 \pm 0.42$ to $5.7 \pm 0.42$ transformants per $10^{6}$ protoplasts, and the GD efficiency varied from $0.5 \pm 0.14$ to $1.7 \pm 0.21$ per $10^{6}$ protoplasts. There was no significant difference among the systems containing 15-25 $\mu \mathrm{g}$ of GHR cassette. When the obtained transformants were analyzed with southern blotting and a hph gene probe, two out of 16 and seven out of 17 transformants obtained with 20 and $25 \mu \mathrm{g}$ of GHR cassette, respectively, showed more than one specific hybridization band, while all the transformants obtained with $15 \mu \mathrm{g}$ of GHR cassette showed only one specific hybridization band (Fig. 3). This result indicated that when the amount of GHR cassette used in the transformation system was more than $15 \mu \mathrm{g}$, the frequency of random insertion increased. Thus, a transformation system with $15 \mu \mathrm{g}$ of GHR cassette was used when the protocol was applied to disrupt a gene in another strain of $B$. dothidea, ZY7. In total, five correct Bdo_05381 disruption transformants were obtained. All the transformants obtained had only one $h p h$ gene locus (Additional file 2: Figure S2). Moreover, we applied this protocol to disrupt another gene (Bdo_02540) in strain HTLW03 and successfully obtained one correct disruption transformant (Additional files 3, 4: Figures S3, S4), although the GD efficiency was lower than that of $B d o_{-}$ 05381 (Table 2). Thus, this method showed great potential for GD in B. dothidea.

\section{Phenotype of GD tranformants}

The gene expression analysis confirmed that Bdo_05381 and Bdo_02540 were up-regulated during melanin accumulation stage (Additional file 5: Figure S5) [25], but their function has not been studied. We speculated that the Bdo_05381 and Bdo_02540 disruption transformants

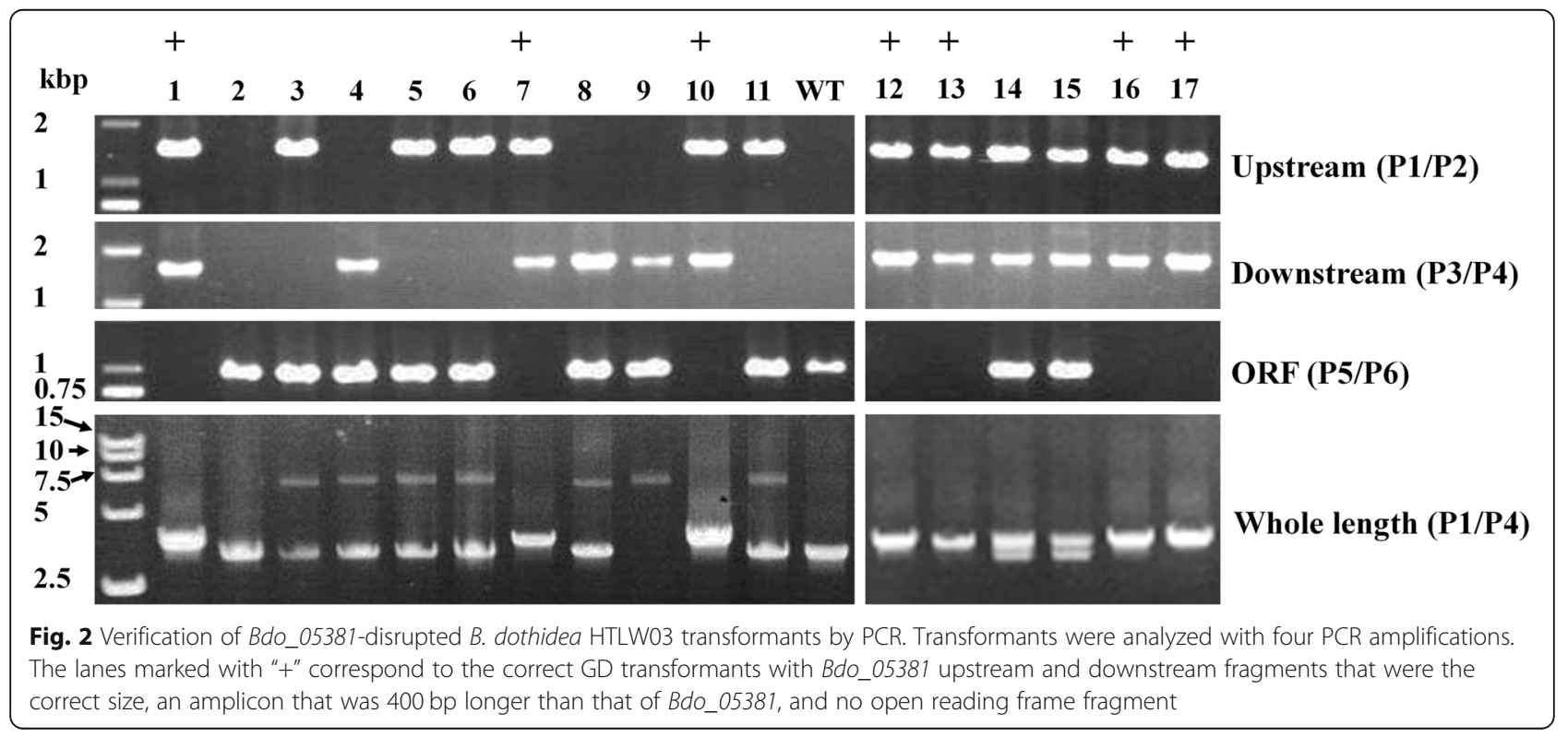


Table 2 Disruption efficiency of transforming B. dothidea HTLW03 strain with cassette DNA

\begin{tabular}{llllll}
\hline Gene ID & $\begin{array}{l}\text { Quantity of } \\
\text { DNA }(\mu \mathrm{g})\end{array}$ & No. of transformants & $\begin{array}{l}\text { No. of correct } \\
\text { transformants }\end{array}$ & $\begin{array}{l}\text { Transformation efficiency } \\
\text { (No. of transformants/10 } 0^{6} \text { protoplasts) }\end{array}$ & $\begin{array}{l}\text { GD efficiency } \\
\text { (No. of transformants/10 } 0^{6} \text { protoplasts) }\end{array}$ \\
\hline Bdo_05381 & 5 & 27 & 5 & $2.7 \pm 0.42$ & $0.5 \pm 0.14 \mathrm{bc}$ \\
& 10 & 38 & 6 & $3.8 \pm 0.56$ & $0.6 \pm 0.28 \mathrm{bc}$ \\
& 15 & 54 & 13 & $5.4 \pm 0.85$ & $1.3 \pm 0.14 \mathrm{ab}$ \\
& 20 & 57 & 16 & $5.7 \pm 0.49$ & $1.6 \pm 0.14 \mathrm{a}$ \\
& 25 & 54 & 17 & $5.4 \pm 0.42$ & $1.7 \pm 0.21 \mathrm{a}$ \\
Bdo_02540 & 15 & 22 & 1 & $2.2 \pm 0.56$ & $0.1 \pm 0.14 \mathrm{C}$
\end{tabular}

Values are means \pm SD from two independent experiments. Values followed with different letters are significantly different $(P<0.05)$ according to ANOVA and Duncan's method

would be altered in melanin accumulation and tolerance to environmental stress. Therefore, colony morphology and tolerance of the disrupted transformants to Congo red and $\mathrm{NaCl}$ were investigated. The $\triangle B d o \_05381-1$ and $\triangle B d o \_05381-2$ showed similar growth rate and resistance to Congo red and $\mathrm{NaCl}$ as the WT, but produced less melanin. The $\triangle B d o \_02540-1$ had a slower growth rate and a stronger resistance to Congo red, but showed similar melanin accumulation and resistance to $\mathrm{NaCl}$ as the WT (Fig. 4).

\section{Discussion}

In this study, we established an efficient GD protocol for the woody plant pathogen $B$. dothidea by using a GHR cassette and optimizing the quantity of transformed DNA in the system. When using $15 \mu \mathrm{g}$ of GHR cassette

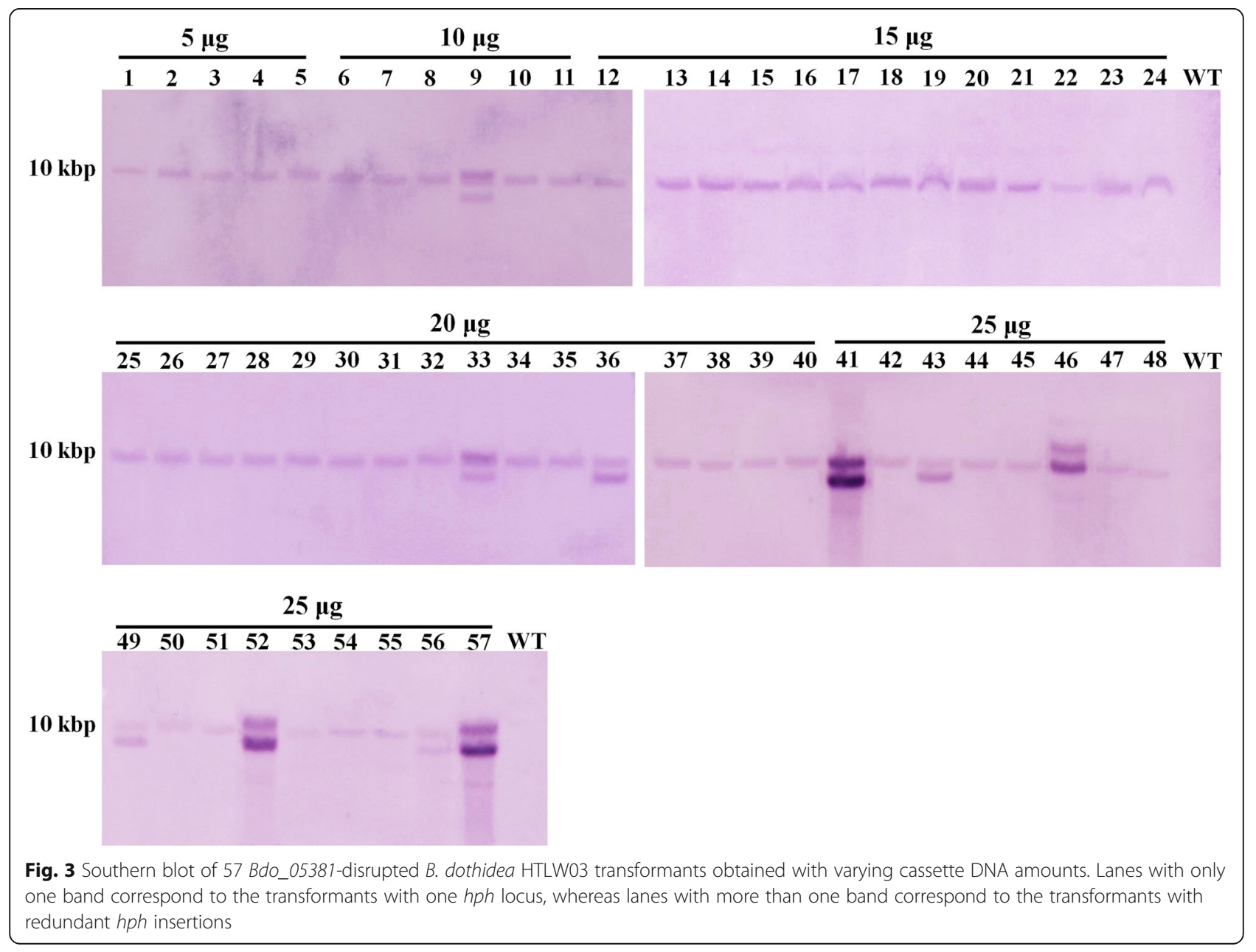




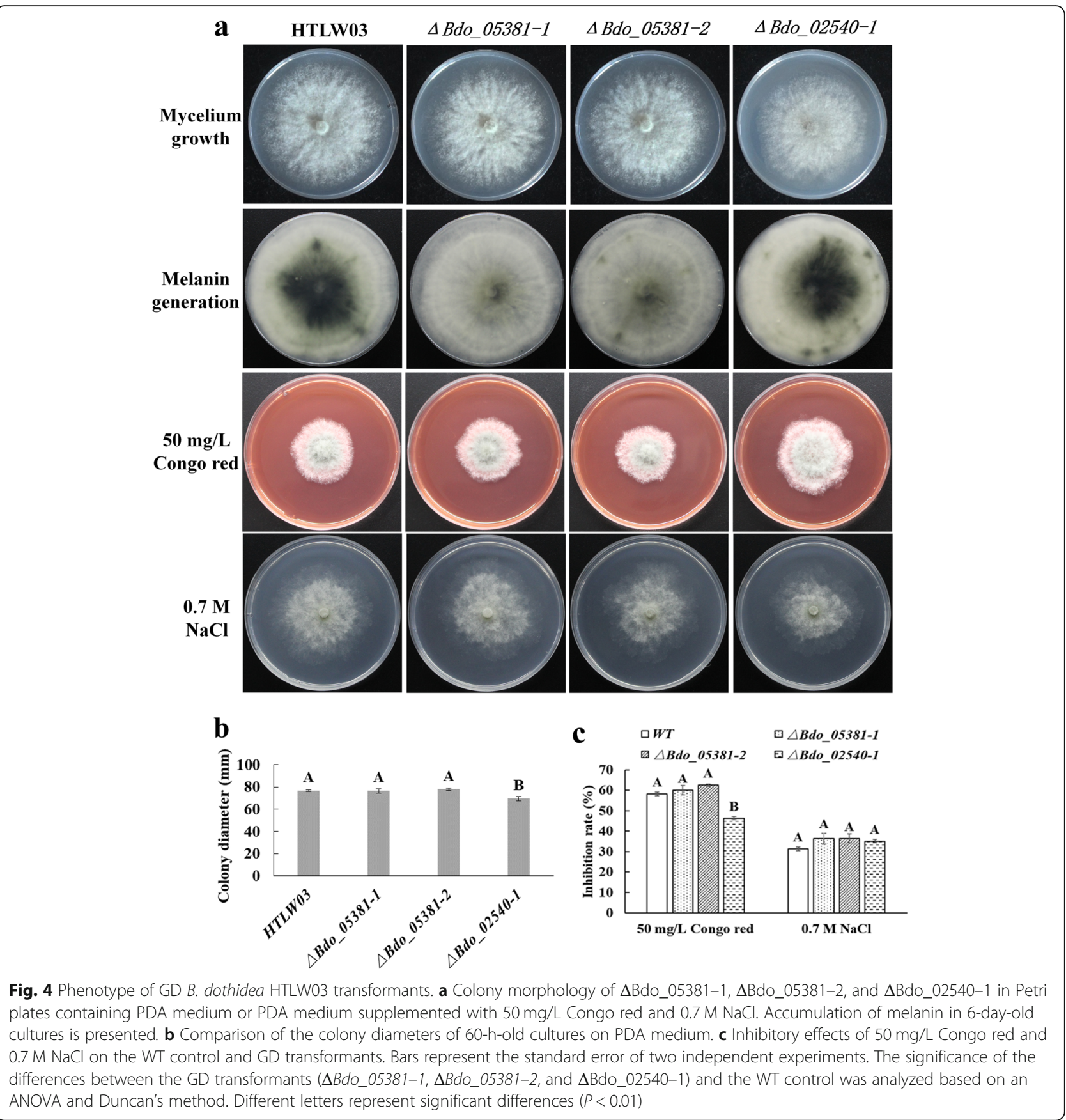

per $10^{6}$ protoplasts, we achieved high GD efficiency $\left(1.3 \pm 0.14\right.$ per $10^{6}$ protoplasts $)$ with low random insertion. We successfully applied this protocol to disrupt genes in two $B$. dothidea strains.

The results of this study showed that when using the same molar mass of GHR cassette and plasmid DNA in the transformation system, the GHR cassette gave much higher GD efficiency than the plasmid. This result agrees with findings in $V$. dahliae [26], Lecanicillium lecanii [27], Fusarium graminearum [28], Candida albicans [29] and Acremonium implicatum [30]. Moreover, although the GD efficiency increased when the GHR cassette quantity was increased from 5 to $25 \mu \mathrm{g}$ per $10^{6}$ protoplasts, multiple insertions occurred when the GHR cassette quantity was more than $15 \mu \mathrm{g}$ per $10^{6}$ protoplasts. Besides, GD efficiency also varied with target genes. In strain HTLW03, GD efficiency of Bdo_02540 is significantly lower than Bdo_05381.

GD by homologous recombination has great potential for studying gene functions, and has been successfully used in many filamentous fungi. In this study, we obtained GD transformants of Bdo_05381 and Bdo_02540 
using homologous recombination successfully. $B d o_{-}$ 05381-disrupted transformants produced less melanin, whereas the Bdo_02540-disrupted transformant showed a slower growth rate and a stronger resistance to Congo red. The function of these two genes remains to be investigated.

The difficulties encountered in B. dothidea GD through homologous recombination are mainly due to (1) low transformation efficiency, which is significantly lower than in other filamentous fungi such as V. dahliae [20] and $M$. oryzae [31]; (2) and the coenocytic situation in its hyphae and conidia. To obtain more transformants, we increased the protoplast concentration (from the commonly used $10^{6}$ to $10^{7} / \mathrm{mL}$ ). Increasing the amount of transformants increased the chance to get correct GD transformants.

In coenocytic fungi, it is only possible to obtain GD transformants containing a single integrated nucleus in one protoplast [32]. Therefore, increasing the percentage of monokaryotic protoplasts is very important to obtain pure GD transformants. In this study, we extended the lysis time for protoplasts to $3.5 \mathrm{~h}$, which is favorable for monokaryotic protoplasts [23]. In fungi with monokaryotic conidia, transformants can be purified via singlespore isolation [33], but this method is not applicable for fungi like $B$. dothidea, which has coenocytic conidia. In this study, we applied three rounds of purification through single-hyphal-tip isolation successively on potato dextrose agar (PDA) plates containing $30 \mu \mathrm{g} / \mathrm{mL}$ hygromycin B, as purified transformants benefited from high selective pressure [33, 34].

\section{Conclusion}

In conclusion, the established GD protocol makes genetic manipulation of the coenocytic woody plant pathogen $B$. dothidea possible. This method provides an efficient approach for researching the pathogenic mechanism of this pathogen and may be applicable to other coenocytic fungi as well.

\section{Methods}

\section{Strain and culture conditions}

Two virulent Botryosphaeria dothidea strains, HTLW03 and ZY7, were used in this study. The strain HTLW03 was isolated from Chinese flowering crabapple in Shandong Province, while ZY7 was isolated from apple in Henan Province. The strains were stored in 30\% glycerin at $4{ }^{\circ} \mathrm{C}$ in the Mycology Lab, College of Plant Protection, China Agricultural University. The WT and transformant strains were maintained on PDA (potato $200 \mathrm{~g} / \mathrm{L}$, dextrose $20 \mathrm{~g} / \mathrm{L}$, agar $15 \mathrm{~g} / \mathrm{L}$ ) plates [23]. To test the abiotic stress sensitivities of each strain, culture blocks (5 $\mathrm{mm}$ in diameter) were placed on PDA plates containing Congo red $(50 \mathrm{mg} / \mathrm{L})$ or $\mathrm{NaCl}(0.7 \mathrm{M})$. Colony diameters were measured after incubating the cultures at $26^{\circ} \mathrm{C}$ in darkness for $60 \mathrm{~h}$. The melanin accumulation in cultures was observed after 6-day incubation. All experiments were performed twice, and each treatment was completed in triplicate.

\section{Protoplast isolation and purification}

Protoplast isolation and purification were performed as described in Chen et al. [23] with some modifications. Briefly, six culture plugs (ca. $0.5 \times 0.5 \mathrm{~cm}$ ) were placed in $100 \mathrm{~mL}$ potato dextrose broth (potato $200 \mathrm{~g} / \mathrm{L}$, dextrose $20 \mathrm{~g} / \mathrm{L})$ and incubated at $26^{\circ} \mathrm{C}$ in a shaker $(50 \mathrm{rpm})$ in darkness for $42 \mathrm{~h}$. The mycelial pellets were centrifuged at $5000 \mathrm{~g}$ for $10 \mathrm{~min}$ in $50 \mathrm{~mL}$ tubes, and then washed twice with $0.7 \mathrm{M} \mathrm{NaCl}$ solution. One gram wet pellet was added to $5 \mathrm{~mL}$ Lysing Enzyme solution (6\% Lysing Enzyme, Sigma, St. Louis, MO, USA; $0.7 \mathrm{M} \mathrm{NaCl}$ ) and the tubes were incubated at $32{ }^{\circ} \mathrm{C}$ for $3.5 \mathrm{~h}$ at $60 \mathrm{rpm}$ for protoplast release. Then, the mixture was filtered through 3-layer lens paper to remove any hyphal fragments, and the infiltrate was centrifuged for $15 \mathrm{~min}$ at $4000 \mathrm{rpm}$. The supernate was discarded and protoplasts in the tube were washed once with STC (1 M sorbitol, $0.1 \mathrm{M}$ Tris- $\mathrm{HCl} \mathrm{pH} \mathrm{8.0,} 0.1 \mathrm{M} \mathrm{CaCl}_{2}$ ) solution to remove residual lysing enzyme and then re-suspended in STC solution. The protoplast concentration was measured with a hemocytometer and diluted to $1 \times 10^{7} / \mathrm{mL}$, and the tubes were stored on ice.

\section{Construction of the GD vector}

The gene sequence including the upstream and downstream regions was retrieved from the Joint Genome Institute (JGI) fungal genome resource (https://genome.jgi. doe.gov/programs/fungi/index.jsf). We generated a GHR plasmid containing a hygromycin-resistance gene (hph) with flanking sequences of the target gene (Fig. 1). The $5^{\prime}$ and 3'-flanking sequences of Bdo_05381 were amplified with Ex Taq (TaKaRa, Dalian, China) and Up-F/R and Down-F/R primers, respectively (Additional file 6: Table S1). The amplicons were purified using an Axygen gel extraction kit (Axygen, Union City, CA, USA). The $h p h$ gene with the $\operatorname{trpC}$ promoter was inserted into the $\mathrm{t}$-clone site of the pMD19-T vector (TaKaRa, Dalian, China). Then, the $5^{\prime}$ and $3^{\prime}$-flanking sequences (1000 bp each) were inserted respectively into the $\mathrm{SacI}$ and Hin$d$ III enzyme digestion sites using a Vazyme one-step cloning kit (Vazyme, Nanjing, China). The GHR plasmid was transferred into Escherichia coli using the heatshock method [35].

\section{Preparation of DNA}

Genomic DNA was extracted using CTAB solution $(2 \%$ $\mathrm{CTAB}, 100 \mathrm{mM}$ Tris- $\mathrm{HCl} \mathrm{pH}$ 8.0, $1.4 \mathrm{M} \mathrm{NaCl}, 2 \%$ polyvinylpyrrolidone, $20 \mathrm{mM}$ EDTA $\mathrm{pH} 8.0$ ) following the DNA extraction protocol described by Kuhad et al. [36]. 
The E. coli was cultured in Luria-Bertani broth (tryptone $10 \mathrm{~g} / \mathrm{L}$, yeast extract $5 \mathrm{~g} / \mathrm{L}, \quad \mathrm{NaCl} 10 \mathrm{~g} / \mathrm{L}$ ) with $100 \mu \mathrm{g} / \mathrm{mL}$ ampicillin at $37^{\circ} \mathrm{C}$ with $180 \mathrm{rpm}$ shaking for $16 \mathrm{~h}$. Then, the plasmid DNA was extracted by the alkaline lysis method [37]. The GHR cassette (the hph gene with the $5^{\prime}$ and $3^{\prime}$ flanking sequences of Bdo_05381) was amplified using the primers Up-F and Down-R (Additional file 6: Table S1, Fig. 1) from the GHR plasmid. The PCR product was precipitated with 0.7 volumes isopropanol and 0.1 volumes $3 \mathrm{M} \mathrm{NaAc}$ ( $\mathrm{pH}$ 5.2). The concentration and quality of the DNA was analyzed using a Nanodrop 2000 Spectrophotometer (Thermo Fisher Scientific, CA, USA).

\section{PEG-mediated transformation}

The PEG-mediated transformation protocols described by Fitzgerald et al. [38] and Zhang et al. [27] were used with some modifications. Various amounts of GHR plasmid or GHR cassette and $100 \mu \mathrm{L}$ protoplasts were placed in $1.5 \mathrm{~mL}$ sterile tubes, and then mixed adequately. After the mixture was kept on ice for $30 \mathrm{~min}, 1 \mathrm{~mL}$ PEG solution (40\% PEG Sigma, $0.1 \mathrm{M} \mathrm{CaCl}_{2}, 0.1 \mathrm{M}$ Tris- $\mathrm{HCl} \mathrm{pH}=$ 8.0) was carefully added dropwise. The tube was then rolled and mixed until the liquids were combined. After incubation at $30^{\circ} \mathrm{C}$ for $30 \mathrm{~min}$, the protoplasts in PEG solution were centrifuged for $8 \mathrm{~min}$ at $2000 \mathrm{~g}$. The supernate was discarded and the pellets were re-suspended with $1 \mathrm{~mL}$ regeneration broth (RB) medium $(0.52 \mathrm{~g} / \mathrm{L}$ $\mathrm{KCl}, 0.52 \mathrm{~g} / \mathrm{L} \quad \mathrm{MgSO}_{4} \cdot 7 \mathrm{H}_{2} \mathrm{O}, 0.25 \mathrm{~g} / \mathrm{L} \quad \mathrm{KH}_{2} \mathrm{PO}_{4}, 6 \mathrm{~g} / \mathrm{L}$ $\mathrm{NaNO}_{3}, 1.2 \mathrm{M}$ sorbitol, $1 \%$ dextrose, $100 \mu \mathrm{g} / \mathrm{mL}$ ampicillin) gently. The suspension was transferred to a $50 \mathrm{~mL}$ tube and diluted using $2 \mathrm{~mL} \mathrm{RB}$ medium. The tube was maintained in a $26^{\circ} \mathrm{C}$ incubator for $12 \mathrm{~h}$.

To screen for resistant colonies, $20 \mathrm{~mL}$ regeneration agar medium (RB medium, $1 \%$ agar, $15 \mu \mathrm{g} / \mathrm{mL}$ hygromycin B) was added to the tube and it was shaken gently. The medium was then distributed into two 9-cm plates and incubated at $26^{\circ} \mathrm{C}$ for $24 \mathrm{~h}$. Subsequently, $15 \mathrm{~mL}$ PDA containing $25 \mu \mathrm{g} / \mathrm{mL}$ hygromycin B was placed on the surface of the plates and they were incubated at $26^{\circ} \mathrm{C}$ in darkness. Colonies rising to the top layer of the medium were transferred to new PDA plates containing $30 \mu \mathrm{g} / \mathrm{mL}$ hygromycin $B$ and sub-cultured for three generations to get pure homologous disruption transformants.

\section{Transformant verification}

The primers designed for analysis are shown in Additional file 6: Table S1. The gene upstream sequence was amplified using the P1 and P2 primers and the downstream sequence was amplified with the P3 and P4 primers. Then, the P5 and P6 primers were used to amplify the open reading frame. The PCR was performed in a $25-\mu \mathrm{L}$ volume containing $2.0 \mathrm{mM} \mathrm{MgCl}_{2}$, $1.0 \mathrm{U}$ of $\mathrm{rTaq}$ polymerase (TaKaRa, Dalian, China),
$200 \mu \mathrm{M}$ each dNTP, $0.4 \mu \mathrm{M}$ each specific primer, and 10-20 ng genomic DNA. The PCR parameters were $94^{\circ} \mathrm{C}$ for $5 \mathrm{~min}$, followed by 30 cycles $\left(94^{\circ} \mathrm{C}\right.$ for $30 \mathrm{~s}$, $58^{\circ} \mathrm{C}$ for $30 \mathrm{~s}$, and $72{ }^{\circ} \mathrm{C}$ for $1 \mathrm{~min}$ ), and a final extension of $72{ }^{\circ} \mathrm{C}$ for $10 \mathrm{~min}$ in a Veriti ${ }^{\mathrm{Tw}}$ 96-Well Thermal Cycler (Thermo Fisher Scientific, CA, USA). The $h p h$ gene was amplified with the P1 and P4 primers using the above PCR protocol, except the polymerase was LA Taq (TaKaRa, Dalian, China) and the extension time was 5 min. The transformation and disruption efficiencies were calculated using the equations:

Transformation efficiency $=$ colonies on the hygromycin B plate/ protoplasts quantity.

Disruption efficiency $=$ correct GD transformants by PCR analysis/ protoplasts quantity.

\section{Southern blot}

Southern blot analysis was used to detect the number of insertion loci of the transformed DNA. The sequence of the resistance gene (ca. $500 \mathrm{bp}$ ) was used for probe labeling. The genomic DNA was digested with the HindIII enzyme (TaKaRa, Dalian, China). Then, the genomic DNA fragments were separated through $0.8 \%$ agarose gel and transferred onto a nylon membrane based on the capillary principle with $20 \times \operatorname{SSC}(3 \mathrm{M} \mathrm{NaCl}, 0.3 \mathrm{M}$ Na-citrate, $\mathrm{pH} 7.0$ ). The digested genomic DNA was probed using a 500-bp $h p h$ gene DNA fragment labeled following the instructions of the DIG High Prime DNA Labeling and Detection Starter Kit I (Roche, Mannheim, Germany).

\section{qRT-PCR analysis}

The qRT-PCR was used to detect the expression pattern of Bdo_05381 and Bdo_02540 in mycelium. The mycelia cultured on PDA plates for 3, 6, and 9-day were collected. RNA was extracted using RNAiso Plus (TaKaRa, Dalian, China), and reversely transcribed with an oligo (dT)18 primer using Reverse Transcriptase M-MLV (TaKaRa, Dalian, China) following the manufacturer's instruction. The Actin was used as internal control. The PCR was performed in qPCR Tower2.0 (Analytik Jena, Germany) using TB Green Premix DimerEraser ${ }^{\mathrm{Tm}}$ qPCR mix (TaKaRa, Dalian, China) following method described by Tao et al. [39]. The results were analyzed using the $2^{-\Delta \Delta c t}$ method [40].

\section{Statistical procedures}

Every treatment contained 10 transformation systems and each repeat contained five systems. Data were analyzed using the SPSS software and significant differences were analyzed according to one-way analysis of variance (ANOVA) and Duncan's method. 


\section{Supplementary information}

Supplementary information accompanies this paper at https://doi.org/10. 1186/s12896-020-00608-z.

\section{Additional file 1: Fig. S1. Predicted PCR products when the homologous recombination occurred only with the upstream or downstream fragment. Solid lines represent the homologous recombination, whereas dashed lines indicate a lack of homologous recombination. a Homologous recombination involving the upstream fragment. b Homologous recombination involving the downstream fragment.}

Additional file 2: Fig. S2. Verification of the Bdo 05381 GD B. dothidea ZY7 transformants. Five Bdo 05381-disrupted transformants were analyzed with four PCR amplifications and a Southern blot. a All transformants comprised the correct upstream (left) and downstream (right) fragments. b Absence of the ORF fragment in the transformants. c Longer whole-length fragment in the transformants than in the WT control. d Southern blot analysis of the hph insertion loci. Lanes 1-5 in a-d correspond to five GD transformants. Lane 6 corresponds to the linearized plasmid (11 kbp).

Additional file 3: Fig. S3. Genomic details regarding Bdo_02540. Arrows represent the primers used for constructing the plasmid and for verifying the transformants by PCR. The restriction enzyme digestion sites are indicated.

Additional file 4: Fig. S4. Verification of Bdo_02540 GD B. dothidea HTLW03 transformants. The Bdo_02540 GD transformant (ABdo_02540-1) was analyzed with four PCR amplifications and a Southern blot. a $\triangle$ Bdo_02540-1 had the correct upstream and downstream fragments, lacked the ORF fragment, and had a longer whole-length fragment than the WT control. b Southern blot analysis of the hph insertion loci.

Additional file 5: Fig. S5. Bdo_02540 and Bdo_05381 expression in mycelium cultured for 3, 6, and 9 days on PDA. The expression in 3-dayold culture with mycelium appeared whitish on the underside of the plate was used as the control. The relative expression levels were calculated according to the $2^{-\Delta \Delta C t}$ method. Bars represent the standard error of three replicates. Different letters represent significant differences according to an ANOVA and Duncan's method $(P<0.05)$.

Additional file 6: Table S1. Primers used for vector construction and transformants analysis. The lowercase represented the homologous sequence flanking the restriction sites of SaCl and HindIII.

\section{Abbreviations}

ANOVA: One-way analysis of variance; GD: Gene disruption; GHR: Gene homologous recombination; ORF: Opening reading frame; PDA: Dextrose agar medium; PEG: Polyethylene glycol; RB: Regeneration broth

\section{Acknowledgements}

Not applicable.

\section{Authors' contributions}

LYG conceived the project, revised the manuscript. BZD designed experiment wrote the manuscript. Both authors read and approved the final manuscript.

\section{Funding}

The research was funded by National Key R\&D Program of China (2016YFD0201100). The funding body had no role in the design of the study and collection, analysis, and interpretation of data and in writing the manuscript.

\section{Availability of data and materials}

The datasets used and analyzed during the current study are available from the corresponding author on reasonable request.

\section{Ethics approval and consent to participate} Not applicable.
Consent for publication

Not applicable.

\section{Competing interests}

The authors declare that they have no competing interests.

Received: 29 September 2019 Accepted: 24 February 2020

Published online: 05 March 2020

\section{References}

1. Marsberg A, Kemler M, Jami F, Jami F, Nagel JH, Postma-Smidt A, Naidoo S, Wingfield MJ, Crous PW, Spatafora JW, Hesse CN, Robbertse B, Slippers B. Botryosphaeria dothidea: a latent pathogen of global importance to woody plant health. Mol Plant Pathol. 2017;18(4):477-88.

2. Mancero-Castillo D, Beckman TG, Harmon PF, Chaparro JX. A major locus for resistance to Botryosphaeria dothidea in Prunus. Tree Genet Genomes. 2018; 14(2):26

3. Yu L, Chen XL, Gao LL, Chen HR, Huang Q. First report of Botryosphaeria dothidea causing canker and shoot blight of Eucalyptus in China. Plant Dis. 2009;93(7):764.

4. Pitt WM, Huang R, Steel CC, Savocchia S. Identification, distribution and current taxonomy of Botryosphaeriaceae species associated with grapevine decline in New South Wales and South Australia. Aust J Grape Wine Res. 2010;16:258-71

5. Zhang CQ, Xu BC. First report of canker on pecan (Carva cathavensis) caused by Botryosphaeria dothidea in China. Plant Dis. 2011;95(10):1319.

6. Milholland RD. Histopathology and pathogenicity of Botryosphaeria dothidea on blueberry stem. Phytopathology. 1972;62(6):654-60.

7. Phillips AJL, Rumbos IC, Alves A, Correia A. Morphology and phylogeny of Botryosphaeria dothidea causing fruit rot of olives. Mycopathologia. 2005; 159:433-9.

8. $\quad$ Tang W, Ding Z, Wang Y, Guo LY. Phylogenetic and pathogenic analyses show that the causal agent of apple ring rot in China is Botryosphaeria dothidea. Plant Dis. 2012:96:486-96.

9. Henson JM, Butler MJ, Day AW. The dark side of the mycelium: melanins of phytopathogenic fungi. Annu Rev Phytopathol. 1999;37(4):447-71.

10. Liu Z, Lian S, Li B, Dong H, Dong X, Wang C. Draft genome sequence of Botryosphaeria dothidea, the pathogen of apple ring rot. Genome Announc. 2016;4(5):1142.

11. Wang B, Liang X, Gleason ML, Zhang R, Sun GY. Comparative genomics of Botryosphaeria dothidea and B. kuwatsukai, causal agents of apple ring rot, reveals both species expansion of pathogenicity-related genes and variation in virulence gene content during speciation. Ima Fungus. 2018:9(2):243-57.

12. Yan JY, Zhao WS, Chen Z, Xing QK, Zhang W, Chethana KWT, Xue MF, Xu JP, Phillips AJL, Wang Y, et al. Comparative genome and transcriptome analyses reveal adaptations to opportunistic infections in woody plant degrading pathogens of Botryosphaeriaceae. DNA Res. 2017. https://doi.org/ 10.1093/dnares/dsx040.

13. Li ZH, Du CM, Zhong YH, Wang TH. Development of a highly efficient gene targeting system allowing rapid genetic manipulations in Penicillium decumbens. Appl Microbiol Biot. 2010;87(3):1065-76.

14. Maruthachalam K, Klosterman SJ, Kang S, Hayes RJ, Subbarao KV. Identification of pathogenicity-related genes in the vascular wilt fungus Verticillium dahilae by Agrobacterium tumefaciens-mediated T-DNA insertional mutagenesis. Mol Biotechnol. 2011;49(3):209-21.

15. Malz S, Grell MN, Thrane C, Maier FJ, Rosager P, Felk A, Albertsen KS, Salomon S, Bohn L, Schafer W, Giese H. Identification of a gene cluster responsible for the biosynthesis of aurofusarin in the Fusarium graminearum species complex. Fungal Genet Biol. 2005;42:420-33.

16. Sakaguchi A, Miyaji T, Tsuji G, Kubo Y. Kelch repeat protein Clkel2p and calcium signaling control appressorium development in Colletotrichum lagenarium. Eukaryot Cell. 2008;7(1):102-11.

17. Nodvig CS, Nielsen JB, Kogle ME, Mortensen UH. A CRISPR-Cas9 system for genetic engineering of filamentous fungi. PLoS One. 2015;10(7):e0133085.

18. Nakayashiki $H$, Nguyen QB. RNA interference: roles in fungal biology. Curr Opin Microbiol. 2008;11(6):494-502.

19. Maier FJ, Malz S, Losch AP, Lacour T, Schafer W. Development of a high efficient gene targeting system for Fusarium graminearum using the disruption of a polyketide synthase gene as a visible marker. FEMS Yeast Res. 2005;5(6-7):653-62. 
20. Klimes A, Dobinson KF. A hydrophobin gene, VDHI, is involved in microsclerotial development and spore viability in the plant pathogen Verticillium dahliae. Fungal Genet and Biol. 2006;43(4):283-94.

21. Chung KR, Lee MH. Split-maker-mediated transformation and targeted gene disruption in filamentous fungi. In: Berg MA, Maruthachalam K, editors. Genetic transformation systems in fungi. Berlin: Springer; 2015. p. 175-80.

22. Capecchi MR. Altering the genome by homologous recombination. Science. 1989;224(4910):1288-92.

23. Chen L, Wang Q, Chen H, Sun G, Liu H, Wang H. Agrobacterium tumefaciensmediated transformation of Botryosphaeria dothidea. World J Microbiol Biotechnol. 2016. https://doi.org/10.1007/s11274-016-2045-0.

24. Song Z, Fan T, Huang L, Gao X, Han Q. Analysis of phenotype and pathogenicity for PEG-mediated mutant library of Botryosphaeria dothidea (in Chinese). Acta Agriculturae Boreali-occidentalis Sinica. 2015;24(2):146-50.

25. Ding Z. Study of the infection process of Botryosphaeria dothidea on apple shoots and identification of a mycovirus infect $B$. dothidea (in Chinese). Beijing: PhD thesis China Agricultural University; 2018.

26. Rehman L, Su X, Guo H, Qi X, Cheng H. Protoplast transformation as a potential platform for exploring gene fuction in Verticillium dahliae. BMC Biotechnol. 2016;16:57-65.

27. Zhang YJ, Xie M, Zhang XL, Peng DL, Yu WB, Li Q, Li Q, Zhao JJ, Zhang ZR Establishment of polyethylene-glycol-mediated protoplast transformantion for Lecanicillium lecanii and development of virulence-enhanced strains against Aphis gossypii. Pest Manag Sci. 2016;72(10):1951-8.

28. Jenczmionka NJ, Maier FJ, Losch AP, Schafer W. Mating, conidiation and pathogenicity of Fusarium graminearum, the main causal agent of the headblight disease of wheat, are regulated by the MAP kinase gpmk1. Curr Genet. 2003:43:87-95.

29. Wilson RB, Dana D, Mitchell AP. Rapid hypothesis testing with Candida albicans through gene disruption with short homology regions. J Bacteriol. 1999;181(6):1868-74

30. Yao YR, Tian XL, Shen BM, Mao ZC, Chen GH, Xie BY. Transformation of the endophytic fungus Acremonium implicatum with GFP and evaluation of its biocontrol effect against Meloidogyne incognita. World J Microbe Biot. 2015; 31(4):549-56.

31. Betts MF, Tucker SL, Galadima N, Meng Y, Patel G, Li L, Donofrio N, Floyd A, Nolin S, Brown D, et al. Development of a high throughput transformation system for insertional mutagenesis in Magnaporthe oryzae. Fungal Genet Biol. 2007:44(10):1035-49.

32. Zeilinger S. Gene disruption in Trichoderma atroviride via Agrobacteriummediated transformation. Curr Genet. 2004;45(1):54-60.

33. Thatcher LF, Gardiner DM, Kazan K, et al. A highly conserved effector in Fusarium oxysporum is required for full virulence on Arabidopsis. Mol Plant Microbe In. 2012:25(2):180-90.

34. Rolland S, Jobic C, Fevre M, Bruel C. Agrobacterium-mediated transformation of Botrytis cinerea, simple purification of monokaryotic transformants and rapid conidia-based identification of the transfer-DNA host genomic DNA flanking sequences. Curr Genet. 2003:44(3):164-71.

35. Froger A, Hall JE. Transformation of Plasmid DNA into E coli using the heat shock method. JoVE. 2007. https://doi.org/10.3791/253.

36. Kuhad RC, Kapoor RK, Lal R. Improving the yield and quality of DNA isolated from white-rot fungi. Folia Microbiol. 2004;49(2):112-6.

37. Sambrook J Molecular cloning a laboratory manual. 3rd ed. Science; 2016.

38. Fitzgerald AM, Mudge AM, Gleave AP, Plummer KM. Agrobacterium and PEG-mediated transformation of the phytopathogen Venturia inaequalis. Mycol Res. 2003;107(7):803-10.

39. Tao Y, Peer AFV, Huang Q, Shao L, Xie B, Jiang Y, Zhu J, Xie B. Identification of novel and robust internal control genes from Volvariella volvacea that are suitable for RT-qPCR in filamentous fungi. Sci Rep. 2016:6:29236.

40. Livak K, Schmittgen T. Analysis of relative gene expression data using tealtime quantitative PCR and the $2^{-\Delta \Delta c t}$ method. Methods. 2000;25(4):402-8.

\section{Publisher's Note}

Springer Nature remains neutral with regard to jurisdictional claims in published maps and institutional affiliations.

\section{Ready to submit your research? Choose BMC and benefit from:}

- fast, convenient online submission

- thorough peer review by experienced researchers in your field

- rapid publication on acceptance

- support for research data, including large and complex data types

- gold Open Access which fosters wider collaboration and increased citations

- maximum visibility for your research: over $100 \mathrm{M}$ website views per year

At BMC, research is always in progress.

Learn more biomedcentral.com/submissions 